Summer 2005

\title{
Reframing the issue: AIDS as a Global Workforce Crisis and the Emerging Role of Multinational Corporations
}

Elizabeth M. Chitty

Indiana University School of Law

Follow this and additional works at: https://www.repository.law.indiana.edu/ijgls

Part of the Business Organizations Law Commons, Health Law and Policy Commons, and the International Law Commons

\section{Recommended Citation}

Chitty, Elizabeth M. (2005) "Reframing the issue: AIDS as a Global Workforce Crisis and the Emerging Role of Multinational Corporations," Indiana Journal of Global Legal Studies: Vol. 12 : Iss. 2 , Article 17. Available at: https://www.repository.law.indiana.edu/ijgls/vol12/iss2/17

This Note is brought to you for free and open access by the Law School Journals at Digital Repository @ Maurer Law. It has been accepted for inclusion in Indiana Journal of Global Legal Studies by an authorized editor of Digital Repository @ Maurer Law. For more information, please contact rvaughan@indiana.edu.

\section{$\Psi$}

JEROME HALL LAW LIBRARY

INDIANA UNIVERSITY

Maurer School of Law
Bloomington 


\title{
Reframing the Issue: AIDS as a Global Workforce Crisis and the Emerging Role of Multinational Corporations
}

\author{
Elizabeth M. Chittr*
}

INTRODUCTION

\begin{abstract}
[Another page, another headline.] "Car plant expansion. 1.5 million rand plan." Ja. I'll tell you what that means ... more machines, bigger buildings ... never any expansion to the pay-packet. Makes me fedup. I know what I'm talking about. I worked at Ford one time. We used to read in the newspaper ... big headlines! ... "So and so from America or London made a big speech: ' . . going to see to it that the conditions of their non-white workers in Southern Africa were substantially improved." The talk ended in the bloody newspaper. Never in the pay-packet. ${ }^{1}$
\end{abstract}

Words first spoken on a Cape Town stage in 1972 capture the negative sentiment expressed regarding the actions and, many times, inactions of multinational corporations (MNCs). From business decisions that range from unfair wage and labor practices to environmental carelessness and pollution, MNCs have been, and continue to be, the target of much criticism. More recently, the response of such corporations to the global AIDS crisis has been challenged by corporate watchdogs, consumer groups, nongovernmental organizations (NGOs), and global leadership alike. The attacks on the seeming inattention of MNCs to the emerging global AIDS epidemic are often voiced in the language of corporate social responsibility. ${ }^{2}$ Critics also present the right to life ${ }^{3}$ - the right to accessible and affordable medical treatment-as a global human rights concern, and in this regard, many fervently argue that MNCs owe an ethical duty to their own employees.

*J.D. candidate, May 2005, Indiana University School of Law-Bloomington. I would like to thank Professor Elizabeth Perry Hodges, Matt Dixon, and Anne Tucker for thoughtful and insightful guidance; I would also like to thank Mr. David Bottorff, Ms. Tracy Souza, and Mr. Jason Rawlings for facilitating and providing feedback on the Cummins Inc. case study.

1. Athol Fugard et al., Sizwe Bansi is Dead, in Statements 3, 3-4 (1986).

2. See infra Part I.A.

3. See id. 
An acknowledgement of a human rights crisis and a demand for corporate social responsibility are not, however, the only means through which to persuade MNCs to act. While philosophical discussion regarding one's underlying motivation to act is important, all sides can agree that the gravity of the AIDS epidemic and devastation resulting from the crisis limit the suitability of this forum for such discussion or debate. ${ }^{4}$ Simply stated, critics of MNCs must learn to speak the language of their audience. In the specific context of the global AIDS crisis and the potential role of MNCs in curbing the spread of, and harm caused by, the disease, the issue must be presented in terms that businesses will both understand and appreciate. Just as "[b]usiness people do not always speak the language often heard from health experts, NGOs or governments," they do not always hear the language often spoken by their critics. Health-field experts speak of disease, treatments, and medicine; NGOs, corporate watchdogs, and consumer groups speak of human rights, including the right of access to medicine; governments speak of citizens and infrastructure. Corporations, however, speak predominantly in terms of costs, productivity, and profits. To motivate and activate the business sector's response to this global crisis, critics must replace any perception of lack of economic benefit on the part of MNCs with recognition of the internal incentive to act. ${ }^{6}$

MNCs have emerged as key participants in the global era-an era which has produced "a state of the world involving networks of interdependence at multi-continental distances." Acknowledging the crucial role that business may play as an intervenor in the global AIDS crisis, the United Nations called on corporations to "[s]trengthen the response to HIV/AIDS in the world of work by establishing and implementing prevention and care programmes in public, pri-

4. See, e.g., Michael Wines \& Sharon LaFraniere, A Hollowed Generation: Plunge in Life Expectancy; Hut by Hut, AIDS Steals Life in a Southern Africa Town, N.Y. TImes, Nov. 28, 2004, §1, at 1 ("[AIDS] has the appearance of a biblical cataclysm, a thousand-year flood of misery and death. In fact, it is all too ordinary. Tiny Lavumisa, [Swaziland] population 2,000, is the template for a demographic plunge taking place in every corner of southern Africa.").

5. Johanna Son, Health-Asia: Fighting HIVIAIDS Makes Business Sense, Oct. 25, 1999, at http:// www. aegis.com/news/ips/1999/1P991013.html (last visited Apr. 6, 2005).

6. Id. (citing an American International Assurance company brief).

7. Robert O. Keohane \& Joseph S. Nye Jr., Globalization: What's New? What's Not? (And So What?), in The Global Transformations Reader 75 (David Held \& Anthony McGrew eds., 2d ed. 2003). 
vate and informal work sectors, and take measures to provide a supportive work place environment for people living with HIV/AIDS."

By creating internal operations that extend "sideways transnationally across national borders," MNCs can be affected in tremendous ways by harmful global conditions, such as the growing AIDS epidemic. Rather than advocating action by MNCs on the basis of corporate social responsibility, presenting the AIDS epidemic as a global workforce crisis provides critics with a meaningful framework through which to urge decisive and immediate effort. The increasing global infection rate among individuals of working age, in addition to the decline in health and well being of the countless people already infected, dramatically impacts both the global workforce on a grand scale and the workforces of discrete MNCs around the world.

By discussing the existing global AIDS epidemic, both in terms of the current framework of a human rights crisis, as well as in terms of the proposed framework of a global workforce crisis, this Note seeks to provide a common language by which MNCs and their critics may engage in productive dialogue. Part I of this Note briefly examines the current framework-AIDS as a global human rights crisis and the response of MNCs through corporate social responsibility. A case study of Cummins Inc. serves to highlight the response, including successes and shortcomings of one corporation's response to the AIDS crisis through the lens of corporate social responsibility. This part concludes with criticisms under the current framework.

Part II proposes an alternative framework through which MNCs, and their critics, may view issues and define responses. A global workforce crisis has emerged as a result of the AIDS epidemic. The disease often affects individuals in their prime working years across populations worldwide. Furthermore, AIDS directly affects the business operations of MNCs through increased costs, decreased productivity, and reduced profits. This part seeks to show that intervention by MNCs is cost-effective, in part by illustrating effective program implementations and their successes. Finally, this part concludes by demonstrating

8. Declaration of Commitment on HIV/AIDS, G.A. Res. S-26/2, U.N. GAOR, 26th Special Sess., Agenda Item 8, at 7, U.N. Doc. A/RES/S-26/2. Ironically, the United Nations, in its role as employer, has been highly criticized for not providing treatment to subcontractors working in the U.N. Gigiri compound in Kenya. See, e.g., John Donnelly, UN Targeted on HIV Coverage Limits, Boston Globe, May 26, 2003, at Al.

9. Philip G. Cerny, The Uneven Pluralization of World Politics, in Globalization in the Twenty-First Century: Convergence or Divergence 153, 155 (Axel Hülsemeyer ed., 2003). 
that reframing the issue in terms of a global workforce crisis may dispel criticisms present under the current corporate social responsibility framework.

\section{Current Framework: AIDS as a Global Human Rights Crisis}

Concern has arisen regarding emerging human rights gaps between the rich and the poor, the powerful and the powerless. Although "the international human rights community" promotes the fundamental idea of basic human rights for all, some worry that the focus still remains too narrow:

[I]f this human rights community does not broaden its analysis and advocacy work to employ an "all rights guaranteed-all actors accountable" framework, it may contribute to the perpetuation of poverty and other injustices on a global scale. The impunity with which many "inter-state," "non-state" and "other state" actors violate the rights of individuals and peoples worldwide may continue unabated. ${ }^{10}$

Acting under the human rights movement umbrella, global leaders, NGOs, and consumer groups seek to hold MNCs accountable for recognizing and addressing the basic human rights of their employees and extended communities in which such corporations operate. In the context of the MNC as employer, the human rights movement utilizes the language of corporate social responsibility.

\section{A. The Right to Life as a Basic Human Right and the Response of MNCs through the} Language of "Corporate Responsibility"

Human rights law is viewed as a powerful means through which to emphasize and redress the global HIV/AIDS crisis. " Corporate responsibility strives to encompass aspects of the human rights movement. ${ }^{12}$ The corporate social responsibility movement addresses a variety of issues in current business practice-

10. Grahame Russell, Human Rights: Seattle, Washington, the IMF, WB, WTO \& Beyond, June 2000, at http://www.rightsaction.org/articles/Archive_O04/0600a.htm (last visited Apr. 6, 2005).

11. Lawrence O. Gostin, The AidS Pandemic, Complacency, Injustice, and Unfulfilled Expectations 61 (2004).

12. Claire Moore Dickerson, Human Rights: The Emerging Norm of Corporate Social Responsibility, 76 Tul. L. Rev. 1431, 1433 (2002). 
including unfair wage and labor practices ${ }^{13}$ and environmental pollution ${ }^{14}$-and it has entered the dialogue surrounding the global AIDS crisis.

The advocacy group Health GAP, for example, strongly promotes access to lifesaving rights as a fundamental human right. ${ }^{15}$ In its fight to ensure implementation of treatment-based workplace AIDS policies, the organization targets MNCs. ${ }^{16}$ Health GAP contends that "[v]irtually all MNCs ... have flouted the most fundamental need among HIV positive workers in the developing world: the urgent need for access to affordable, life-extending HIV treatment and care." organization further argues that "multinational corporations have 'responsibilities' as global citizens and as employers to initiate and support efforts to alleviate the HIV/AIDS pandemic, particularly among their employees, [as] they are also individually and collectively 'responsible' in another sense-they too have engaged in practices and policies that have intensified the pandemic." ${ }^{18}$ Additional advocacy, consumer, and corporate watchdog groups use "naming and shaming campaigns"19 and similar tactics to draw attention to the actions of MNCs that they feel do not live up to the true meaning of corporate social responsibility.

Volunteerism serves as a means for establishing minimal duty as "[m]ost large companies nowadays acknowledge some form of responsibility for corporate citizenship; many make specific reference to this in their Annual Reports and other corporate literature." ${ }^{20}$ Such volunteerism can exist as a product of

13. Behzad Yaghmaian, A Global AIDS Fund and a Living Wage Campaign, Counterpunch, July 3, 2002, at http://www.counterpunch.org/behzad0703.html (last visited Apr. 15, 2005) ("Boycotting or calling for a ban on the import of goods made by child labor or under sweatshop conditions have become a cornerstone of the anti-globalization protests.").

14. Son, supra note 5 (quoting a brief from the firm PT Freeport Mining in Indonesia which expressed that "[e]xtractive mining industries are frequently under the gun from environmental and other groups for damage done by mining, overburdened management and related environmental and social impacts").

15. See Health Global Access Project (GAP), About Health GAP, at http://www.healthgap.org/ hgap/about.html (last visited Apr. 6, 2005).

16. See Health GAP, Corporate Best Practice Must Include AIDS Treatment Access, at http:// www.globaltreatmentaccess.org/content/press_releases/02/020102_HGAP_PP_MNC.pdf (last visited Apr. 6, 2005).

17. Id. at 1 .

18. Brook K. Baker, Corporate Complicity in the African AIDS Pandemic, 1 (2002), available at http://www.treat-your-workers.org/091802_HG_PP_MNC_Comp.pdf (last visited A pr. 6, 2005).

19. Id. at 3 .

20. Leslie Sklair, Transnational Practices and the Analysis of the Global System, in GLobalization in the Twenty-First Century: Convergence or Divergence, supra note 9, at 15, 27. 
self-initiated general corporate codes of conduct. On the international level, "soft law" regarding corporate social responsibility has also emerged. ${ }^{21}$ Critics, however, argue that the international codes lack sufficient substance to adequately address the growing demands of the AIDS crisis. Health GAP disclaims the benefit of such soft, nonlegally binding law that attempts to set guidelines for the role of MNCs in the AIDS crisis. Health GAP's criticisms are that:

[B]y refusing to present corporations a coherent mandate for workplace treatment programs, these initiatives do more harm than good. The GHI [Global Health Initiative], for example, in adopting the ILO [International Labour Organization] HIV/ AIDS code as "business best practice" for HIV/AIDS, sets an eminently low standard for businesses to meet in the area of providing workplace treatment. This "best practice" offers no added benefit to a worker faced with sickness and death from untreated HIV disease, but provides MNCs with all the benefits that accompany compliance with international standards, no matter how weak. ${ }^{22}$

Despite the numerous criticisms aimed at the lack of substance and enforcement mechanisms of the current corporate responsibility movement, many MNCs have employed corporate social responsibility as a framework for their responses to the emerging global AIDS crisis. The following case study highlights the actions of one such corporation.

\section{B. Case Study: Cummins Inc.}

Cummins Inc. is an MNC headquartered in Columbus, Indiana. ${ }^{23}$ Its business operations (including manufacturing plants, research facilities, sales offices, and over 500 company-owned and independent distributor locations) extend throughout 131 countries and territories; globally, Cummins employs 23,700

21. See infra note 32 and accompanying text.

22. Health GAP, supra note 16 , at 1 .

23. Except as otherwise provided, the information presented in this case study was gathered during a telephone interview with Tracy Souza, Executive Director Corporate Social Responsibility, Cummins Inc. (Nov. 20, 2003). 
individuals. ${ }^{24} \mathrm{~A}$ key feature of this $\mathrm{MNC}$ is its decentralized corporate structure, consisting of four distinct business units and regional headquarters located around the world.

One aspect of Cummins's mission is to act in the best interests of all stakeholders; importantly, the corporation defines stakeholders broadly to include, among others, both employees and the communities in which the corporation operates. ${ }^{25}$ Additionally, Cummins upholds six core values: integrity, innovation, delivering superior results, corporate responsibility, diversity, and global involvement. ${ }^{26}$ Cummins's corporate social responsibility initiatives take place in part through the activities of The Cummins Foundation, whose mission is to "make people's lives better by: [s]erving and improving the communities in which Cummins Inc. does business, and [p]roviding the tools and means for people living on the edge of society to overcome the barriers they face." 27

Cummins's commitment to the best interests of its stakeholders as well as to corporate responsibility has led to the company's involvement in the global fight against HIV/AIDS. Cummins's overarching philosophy, in combination with its decentralized corporate structure, allows specific policy and program implementation to occur on a local level. Rather than mandate company-wide policies, Cummins's strategy in addressing any prevailing issue truly embodies the motto "think globally, act locally."

The HIV/AIDS crisis illustrates both the necessity and increased effectiveness of acting at the local level and serves as a reminder that one approach rarely fits the needs of all. Although Cummins does not track statistics regarding HIV/ AIDS infection among its employees, it is clear that a fairly significant mass of its South African employees, where the rate of infection has drastically increased, are affected by this virus. Here, Cummins has partnered with the Careways Group, ${ }^{28}$ an independent for-profit organization, in assisting with employee training and administration needs. Within its Mexican region and its Latin

24. See Cummins Inc., Who We Are, at http://www.cummins.com/na/pages/en/whoweare/ vision_mission.cfm (last visited Feb. 25, 2005).

25. Shareholders and governments are also included in this broad definition of stakeholders.

26. Cummins Inc., supra note 24.

27. Cummins Foundation, at http://www.cummins.com/na/pages/en/whoweare/foundation. cfm (last visited Apr. 6, 2005).

28. See generally The Careways Group, at http:/www.bodyiq.co.za/partnersCareways.html (last visited Apr. 6, 2005) ("The Careways Group markets Wellness programmes to its corporate clients: helping companies make the most of their human capital by achieving and maintaining an optimum level of mental and physical health."). 
American region (which includes Brazil), Cummins has begun employee training with a focus on HIV/AIDS education.

In India, the Cummins Foundation is currently working to develop a prevention and education program targeting local truck stop routes. ${ }^{29}$ The Cummins Foundation is also in the process of exploring possibilities of partnering with Project Concern International ${ }^{30}$ and the Bill and Melinda Gates Foundation ${ }^{31}$ in fighting this deadly disease in India.

Cummins recognizes that AIDS is a moral, social, and health concern. Its decisions regarding similarly sensitive issues confirm the need to create and implement guidelines and procedures at a local level. Cultural norms vary from one operating location to the next, and effectiveness requires that such differences be taken into consideration when determining the most appropriate response. Both approaching the HIV/AIDS crisis in a location- and culture-specific manner and recognizing the global dimension of the HIV/AIDS crisis have led Cummins to realize that one of the greatest hurdles in determining the most effective components of a solution is the lack of a good "roadmap."

\section{Limitations to Viewing Business Response through a Framework of Corporate Responsibility}

\section{Voluntary Nature and Lack of Enforcement Power}

A fundamental criticism of corporate social responsibility is its voluntary nature and lack of enforcement power. While a host of "soft law" governs corporate responsibility, ${ }^{32}$ it lacks true power of enforcement. Moreover, developing

29. Mapping and documentation show that truck stops significantly contribute to the spread of $\mathrm{HIV}$ in this region.

30. See generally Project Concern International, at http://www.projectconcern.org (last visited Mar. 2, 2005) ("Project Concern saves the lives of children and families around the world by preventing disease and providing access to clean water and nutritious food.").

31. See generally Bill \& Melinda Gates Foundation, at http:/www.gatesfoundation.org/default (last visited Apr. 6, 2005) ("Bringing innovations in health and learning to the global community").

32. See, e.g., International Labour Organization (ILO), Tripartite Declaration of Principles Concerning Multinational Enterprises and Social Policy, available at http:/ www.ilo.org/public/english/standards/norm/sources/mne.htm (adopted Nov. 1977); UNITED NAtions Conference on Trade and Development, The Social Responsibility of Transnational Corporations, available at http:/www.UNCTAD.org/en/docs/poiteiitm21.en.pdf (1999); THE OECD Guidelines for Multinational Enterprises, available at http:/www.oecd.org/ document/28/0,2340,en_2649_34889_2397532_1_1_1_1,00.html (Revision 2000); AN ILO CoDE $\mathrm{mmmm}$ 
countries eager to attract foreign investment and maintain operations of MNCs may be hesitant to impose legal duties out of fear of dissuading the corporations from pursuing development in that country. ${ }^{33}$ Critics further suggest that if MNCs feel too much pressure from the local government, NGOs, or workers to provide AIDS treatment, the corporations may threaten "capital flight." 34

\section{The "Bottom Line" as Multinational Corporations' Only Concern}

Actions taken by MNCs are often greeted with skepticism. AIDS advocates and corporate watchdog groups question the motivation of corporations, ${ }^{35}$ who, these critics allege, are too concerned with the "bottom line" of profit making, to the exclusion of legitimate worker issues. ${ }^{36}$ They claim that in addition to seeking powerless population groups to exploit for profit, MNCs often wield their influence to earn favorable results in "manipulated international trade pacts and agreements, in order to maximize profits." 37

\section{Insufficiency/Nonsustainability of the Current Response of MNCs}

The current response of MNCs to the global AIDS crisis has been criticized in at least two ways. First, many AIDS advocates strongly believe that the re-

of Practice on HIV/AIDS AND THE WORLD of WoRK, available at http://www.ilo.org/public/ english/protection/trav/aids/code/languages/hiv_a4_e.pdf (2001) [hereinafter CoDE of Practice]; and United Nations, Economic and Social Council, Commission on Human Rights; Economic, Social and Cultural Rights: Norms on the Responsibilities of Transnational Corporations and Other Business Enterprises with Regard to Human Rights, U.N. Doc. E/CN.4/ Sub.2/2003/12/Rev.2.

33. See, e.g., Yaghmaian, supra note 13 (discussing "destructive wage competition"). But see ILOAIDS, Collection of National Instruments Related to HIVIAIDS and the World of Work, at http:/ /www.ilo.org/public/english/protection/trav/aids/laws/index.htm (last modified Jan. 19, 2005) ("This collection contains legislative texts (hard law) and soft law instruments (codes of practice, guidelines, policies) dealing, entirely or in part, with HIV/AIDS and the world of work.").

34. Yaghmaian, supra note 13 (discussing the threat of "capital flight" in the context of wage law).

35. For example, a member of the Health Gap Coalition, Asia Russell, suggests that "[i]t's almost like some [corporations] are making statements to calm investors above all else. They talk about doing the right things for the wrong reasons." John Donnelly, Activists Hope Firms' Involvement Boosts Battle Against AIDS in Africa, Boston Globe, Sept. 4, 2001, at D1.

36. See Anup Shah, Corporations and Human Rights, at http://www.globalissues.org/TradeRelated/Corporations/HumanRights.asp (last modified Sept. 19, 2002).

37. Id. (citation omitted). 
sponses of MNCs, even those who have acted, are simply insufficient ${ }^{38}$ For example, where MNCs have implemented prevention programs, some critics feel that treatment programs are necessary. ${ }^{39}$ Where MNCs have implemented treatment programs, others feel that the programs do not reach as many workers as necessary or that they exact too great a financial burden from those benefiting. ${ }^{40}$ Many of the "naming and shaming campaigns" focus not on the MNCs that have managed to entirely sidestep the issue, but rather on those that make public promises of actions that have failed to be fully implemented or fail to reach as broadly as critics would like. ${ }^{41}$

Second, responses of MNCs through philanthropic donations or established corporate "foundations" are viewed as insufficient and nonsustainable. Critics argue that "[p]rivate charities, even if they are guided by good intentions, cannot make a dent into this problem," ${ }^{42}$ and that long-lasting solutions involve more than philanthropic gestures. They believe that corporate donor programs ${ }^{43}$ and pharmaceutical companies' reductions in antiretroviral drug prices are equally nonsustainable. ${ }^{44}$

The framework of corporate social responsibility remains vulnerable as a result of its inherent shortcomings. Those who view and challenge the response

38. See, e.g., Baker, supra note 18 ("[S]ome MNCs are beginning to acknowledge the scope of the pandemic and plan minimal face-saving responses that protect limited segments of their skilled workforce.").

39. See id.

40. See, e.g., id. (criticizing the 2001 decision of Anglo-American subsidiary AngloGold "to offer ARV therapy to office and management staff only, mostly white, but not to frontline miners, mostly [b]lack" and the decision of DeBeers "to provide coverage to one dependant and to workers and that dependant for life, but ... to impose a $10 \%$ co-pay which could cost workers hundreds of dollars a year").

41. See, e.g., id. (praising the success of campaigns against corporations such as AngloGold and DeBeers).

42. Yaghmaian, supra note 13 ("Africans will die in rising numbers while we debate the merits of free market capitalism, and wait for the kind-heartedness of pharmaceutical firms to lower their prices for distribution in Africa.").

43. Health GAP, supra note 15 ("Sustained access [to life-saving drugs] cannot result from industry-controlled charity programs.").

44. Rachel Cohen, Wealthy Countries Should Help Developing Countries Acquire AIDS Drugs, in AIDS: Opposing Viewpoints 52, 56-57 (Tamara L. Roleff ed., 2003) ("It is critical that a longterm, sustainable solution to the crisis of lack of access to medicines be developed-not one that relies solely on the good will of pharmaceutical companies to voluntarily offer discounts on certain medicines. Though such price reductions are important, they are extremely vulnerable strategies on their own."). 
to the AIDS crisis solely in this limited fashion also fail to accurately capture the devastation that MNCs may experience. ${ }^{45}$ This occurs in spite of the fact that "AIDS is no longer just a niche issue for companies wishing to demonstrate corporate leadership to a particular group important to their business. It is one of the defining global issues that will affect market development and the performance of individual companies over the next half century." ${ }^{36}$ While MNCs may care about the global AIDS epidemic as a human rights crisis in terms of corporate social responsibility (and arguably should), they must care about the epidemic as a threat to the global workforce.

\section{Proposed Framework: AidS as a Global Workforce Crisis And the Emerging Role of MNCs}

The proposed framework, as compared to the current framework of corporate social responsibility, builds on the premise that "business' main business is

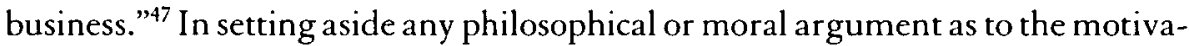
tion that should drive corporate response, this framework focuses on a pragmatic approach: MNCs must treat the AIDS crisis as an emerging business issue. ${ }^{48}$ More poetically phrased, "HIV/AIDS is a matter of enlightened self-interest." ${ }^{\text {" }}$ MNCs must take action against the growing AIDS epidemic, not simply as a matter of corporate responsibility, but to protect their interests in maintaining the global workforce.

MNCs have a vested interest in preserving human capital as one of many elements necessary to operate any business. The AIDS crisis affects populations around the world and particularly targets individuals of working age $;^{50}$ the epi-

45. See ILO, HIV/AIDS and Work: Global Estimates, Impact and Response 34 (2004) [hereinafter HIV/AIDS AND WORK] ("[B]y not addressing the human capital and labour force implications of HIV/AIDS, the global community will fail to avert a potential developmental catastrophe-for Africa, in the first instance, but with impacts in all regions.").

46. Ben Plumley et. al., Beyond the Workplace: Business Participation in the MultiSectoral Response to HIV/AIDS (Global Business Coalition on AIDS, Discussion Paper, 2002).

47. Klaus Schwab, Foreword to World Economic Forum, Business and HIV/AIDS: Who Me? A Global Review of the Business Response to HIV/AIDS, 2003-2004, at I (Kate Taylor \& Peter DeYoung eds., abr. version 2003) [hereinafter Business and HIV/AIDS].

48. ILO, Action Against AIDS in the Work place: The Asia-Pacific Region (2002) [hereinafter Action AGainst AIDS] ("Successful businesses are those that adapt to the changing environment in which they operate.").

49. Id.

50. See infra Part II.A. 
demic also impinges on day-to-day business operations in very tangible ways. ${ }^{51}$ Proponents of this view can persuade MNCs to immediate and determined action by explaining the effects of the AIDS crisis in economic terms, by focusing attention on the imminent threat to the global workforce, and by highlighting the cost-effectiveness and positive impact of intervention. ${ }^{52}$

\section{A. AIDS Affects Individuals Across Populations Worldwide in the Prime of Their Working Years}

The HIV/AIDS crisis continues to worsen. Almost 5 million individuals became HIV-positive in 2003 alone-the highest rate of infection in a single year since the epidemic began. ${ }^{53}$ The AIDS pandemic is undeniably global in nature, leaving no area of the world unaffected. The disease, however, strikes different regions and countries in dramatically varying degrees. ${ }^{54}$ Countries hard hit by the epidemic experience a shortened life expectancy. ${ }^{55}$ AIDS has devastated the African continent, ${ }^{56}$ where the average life expectancy of individuals born between 1995 and 2000 is at present forty-nine years of age (a drop of thirteen years) in seven Afri-

51. See infra Part II.B.

52. Richard Holbrooke, president of the Global Business Council on HIV/AIDS, echoes this view: "I understand that businesses need to do things in their own interests, so we have to show businesses that it is in their own interests to work on this problem." Donnelly, supra note 35 (emphasis added).

53. UNAIDS, 2004 Report on the Global AIDS Epidemic: Executive Summary 5 (2004) [hereinafter 2004 RePORT].

54. Id. at 5-7. In Asia, 7.4 million people currently live with HIV infection. Id. at 5. While countries such as Cambodia and Thailand have reduced infection rates by targeting risky behavior, the disease continues to rage in India, which ranks second, only to South Africa, in number of HIVpositive individuals. Id. at 6 . Sub-Saharan Africa is home to an estimated 25 million HIV-positive individuals; while the rate of infection appears to have stabilized, this is predominantly a result of an increase in AIDS-related deaths while the rate of new infections simultaneously has increased. Id. Approximately 480,000 infected individuals live in the Middle East and North Africa. Id. The epidemic continues to spread in Central Asia and Eastern Europe, where some 1.3 million people live with the disease. Id. at 7. Similarly, HIV has affected 1.6 million people living in Latin America. Id. In the Caribbean, 430,000 individuals are HIV-positive, with three countries having an infection rate of $3 \%$ or more. Id. Even high-income regions, including the United States and Western Europe, are experiencing an increase in infection rates, with 1.6 million individuals currently infected. Id.

55. HIV/AIDS AND WORK, supra note 45 , at 10 (charting the male and female life expectancy projections, both with and without the disease, in the 10 countries most affected by HIV/AIDS).

56. See id. at 4 (noting that the average regional frequency of HIV infection among working aged individuals is $7.7 \%$ ). 
can countries with a population-wide infection rate higher than 20 percent. ${ }^{57}$ In Zimbabwe, Zambia, and Swaziland, the life expectancy is forecasted to fall below thirty-five years of age without the implementation of treatment programs. ${ }^{58}$

In addition to severely reducing life expectancy rates, HIV/AIDS can dramatically alter existing population patterns: "[w|hen there is a major HIV/AIDS epidemic, large sections of infants could die due to Mother to Child Transmission. This combined with high mortality rate in the reproductive age group and unchanged mortality pattern among the elderly produces a 'chimney pattern." 59 Such long-term modifications to basic population structures carry grave implications for the present, as well as the future, state of affairs. The AIDS-induced collapse of family and community structure generally, including the premature death of caregivers and the increasing number of orphaned children, further decreases the viability of future workforces. ${ }^{60}$

Impact on the global workforce is compounded by the fact that AIDS affects individuals in the prime of their working years. ${ }^{61}$ Of the almost 38 million persons estimated to have been living with HIV/AIDS by the end of 2003, 36 million are of working age. ${ }^{62}$ Further estimates suggest that 26 million HIVpositive individuals are active in the global workforce. ${ }^{63}$ These statistics highlight the reality that "[t]he spread of the [AIDS] virus has harmed the economies of many developing countries, draining them of workers and depressing their

57. 2004 REPORT, supra note 53, at 8 (warning that "[i]n the worst-affected countries of eastern and southern Africa, if current infection rates continue and there is no large-scale treatment programme, up to $60 \%$ of today's 15 -year-olds will not reach their 60 th birthday.").

58. Id.

59. United Nations Development Programme, AidS at Workplace (2004), at hitp:// www.youandaids.org/Themes/Aidsatworkplace.asp (last visited Apr. 6, 2005) (explaining that "[t]he usual population structure has a 'pyramidal pattern' with the maximum number of individuals in infancy and the number coming down gradually as the age rises.").

60. See HIV/AIDS AND WORK, supra note 45, at 6 (suggesting that "the long-term costs of ignoring the role of the family in preparing future generations for productive work, and in the creation of the human capacity for socio-economic development, [have] not yet been appraised at [their] true value."); see also id. at 10.

61. Id. at 10; 2004 Report, supra note 53, at 9; Code of Practice, supra note 32, at iii ("[AIDS] is affecting the most productive segment of the labour force."); Action AGainst AIDS, supra note 48 ("HIV/AIDS is changing the age and sex distribution of the labour force, causing a loss of skills and experience, and jeopardizing human resource development.").

62. HIV/AIDS AND WoRk, supra note 45, at V, XI. Working age is defined as 15 to 49 years of age. See id. at XI.

63. Id. at XI (suggesting that $73 \%$ of those infected with AIDS are active in the workforce). 
agricultural and industrial sectors." ${ }^{64}$ The International Labour Organization projects that by 2020 , the workforce population in thirty-two African countries will have decreased in size by 5 percent to 35 percent as a result of the AIDS epidemic. ${ }^{65}$ Without increases in essential AIDS treatment, the aggregate loss of members of the global workforce is predicted to total 28 million by $2005 .{ }^{66}$ This number, if current prevention and treatment practices remain unchanged, will increase to 48 million by 2010 and to 74 million by $2015 .{ }^{67}$

Certain business sectors remain more susceptible to the threat of HIV/AIDS than others. For example, those sectors employing a workforce predominantly removed from family and community, such as the mining industry, experience a heightened risk of transmission among the workers ${ }^{68}$ Many times, workers in this industry, as well as industries which utilize mobile or migratory workforces, are housed in all-male housing close to the worksite, and sex workers often reside nearby. ${ }^{69}$ Not only does the isolated environment suggest increased rates of infection, but HIV/AIDS infection spreads to the remote towns and villages upon the workers' return. ${ }^{70}$ Workers engaged in the transportation sector, including the trucking industry, similarly are exposed to an above-average risk of infection. ${ }^{11}$ With regard to such mobile workforces, HIV/AIDS infection spreads throughout the region when workers engage in high-risk behavior and then move about as their employment responsibilities dictate. ${ }^{72}$

64. Peter Currie, How Can Resources Be Mobilized to Confront a Global Health Emergency?-An Introduction to the Problem, 4 Yale J. Health Pol'y, L. \& Ethics 125, 125 (2004).

65. Ilo, Action Against AidS in the Workplace: The Africa Region (June 2003) [hereinafter Action Against AIDS: The Africa Region].

66. HIV/AIDS AND WoRK, supra note 45, at XI.

67. Id. Put in perspective, losing 74 million people to AIDS is comparable to the entire population of South Africa or Thailand simply vanishing. Id. at 7.

68. Id. at 16-17 (comparing the prevalence of HIV in South Africa, Botswana, and Zambia across industries, including mining, manufacturing, and metal processing); see also Susan S. Hunter, BlaCk Death: AIDS IN Africa 24-25 (2003) (suggesting that long periods away from family members combined with all-male living arrangements while on the job site have contributed to the increase in risky behavior and consequently the increase of $\mathrm{HIV}$-infection in this industry).

69. See, e.g., Baker, supra note 18.

70. Id.

71. HIV/AIDS AND WoRK, supra note 45, at 41; id. at 45-46 (describing an AIDS-prevention initiative by Shell Company of Thailand identifying and targeting gas stations as "points of risk" for the stopped drivers as well as the local sex workers); supra note 24, and accompanying text.

72. See, e.g., Baker, supra note 18 ("Multinational corporations have insisted on the development of transportation infrastructures, but have made no provision to prevent or reduce HIV transmission along truck routes, at sea ports, and along other systems of transportation."). 


\section{B. AIDS Directly Affects the Operations of MNCs}

The AIDS epidemic not only affects the make-up and viability of the current and future population structure and the viability of the global workforce, but also directly and indirectly shapes the current business operations of MNCs on a day-to-day basis. ${ }^{73}$ The epidemic has resulted in increased costs, decreased productivity, and reduced profits for many companies, the effects of which are often interconnected. ${ }^{74}$

\section{AIDS Results in Increased Costs to the Corporation}

Estimates suggest that by 2005, the physical repercussions of AIDS will force 2 million members out of the workforce entirely, and by 2015, more than 4 million workers will be unable to continue active employment. ${ }^{75}$ Even now, African companies sometimes hire two employees per position because of the likelihood that AIDS will render one unable to work. ${ }^{76}$ For MNCs providing health care benefits to their employees, the cost of insurance premiums and claims will inevitably rise. ${ }^{77}$ Additional costs accrue as a result of the necessary recruiting and training of new employees to replace those workers debilitated and unable to continue working due to the physical effects of AIDS. Such an increase in employee turnover also leads generally to a less-trained and less-skilled workforce. The ever increasing price of health care, the reduction of experienced and skilled workers due to sickness and death, and AIDS-related absenteeism are among the leading

73. See HIV/AIDS AND WoRK, supra note 45, at 11-12; see also 2004 Report, supra note 53, at 10; International Finance Corporation, HIV/aIDS in the Workplace 1, 3 (2002) [hereinafter HIV/AIDS in THE WORKPLACE]. The agricultural sectors of many developing nations have also experienced a reduction in labor and productivity as a result of the AIDS epidemic. See, e.g., A.L. Abate et al., Understanding the Impact and Expanding the Response of the Farming Sector to HIVI AIDS in Namibia, in Government Leaders in Namibia Responding to the HIV/AIDS Epidemic 107 (Barnabas Otaala ed., 2003).

74. See Action Against AIDS, supra note 48 (chart illustrating "how these costs combine and reinforce each other to reduce the revenue and profits of enterprises."). While the chart indicates many possible negative effects of AIDS on the workplace, it is important to note that not every aspect of AIDS in the workplace may affect each MNC, or at least not to the same extent.

75. HIV/AIDS AND Work, supra note 45, at XI.

76. See, e.g., Greg Behrman, The Invisible People: How the U.S. Has Slept Through the Global AIDS Pandemic, the Greatest Humanitarian Catastrophe of Our Time (2004), at xii. For example, in one African country, Standard Chartered Bank recognized that about $10 \%$ of the company's staff was absent on any one day due to HIV/AIDS-related issues. Business AND HIV/ AIDS, supra note 47, at III.

77. See Action Against AIDS, supra note 48. 
factors resulting in direct cost increases to $\mathrm{MNCs} .^{78}$ Additional business expenditures may also accrue as AIDS affects the supply chain's network of suppliers and distributors. ${ }^{79}$

\section{AIDS Results in Decreased Productivity within the Corporation}

In the words of Mervyn Davies, Group Chief Executive for Standard Chartered Bank, "AIDS imposes a day-to-day economic 'tax' that compromises business productivity." 80 Productivity is lowered as AIDS begins to affect the physical well being of an MNC's employees. A skilled worker may at first merely become slow at his job, but as the disease continues to take its toll, absence from the workplace frequently occurs. Eventually, the employee becomes incapacitated to the point that work is no longer a possibility and he must suspend or quit his employment. Productivity remains decreased until the position is filled once again, but even then, a new employee will not be at full production capacity for a number of weeks or months, depending on the skill involved. AIDS increases costs to the corporation and wages war on the very source of productivity, thereby reducing profits.

\section{AIDS Results in Declining Profits for the Corporation}

Beyond the increased costs and decreased productivity that result from the epidemic's direct attack upon members of the workforce worldwide, MNCs also experience a decline in profit as AIDS affects the customers of any given business. ${ }^{81}$ Current trends support the conclusion that AIDS affects the supply end of business more dramatically than the demand end; however, 30 percent of the firms studied by the South African Business Coalition on HIV/AIDS believe that over the next five years, the AIDS crisis will negatively affect sales. ${ }^{82}$ Shrinking regional markets are further affected as ill breadwinners are no longer able to work and thus lose the ability both to earn income and support their families. ${ }^{83}$ The tremendous financial burdens on remaining family mem-

78. HIV/AIDS AND WORK, supra note 45, at XII. In Kenya \& Botswana, firms studied attributed more than $50 \%$ of HIV/AIDS-related labor costs to absenteeism. Id. at 11; see also HIV/AIDS IN THE WORK PLACE, sUpra note 73, at 3.

79. HIV/AIDS IN THE WORK PLACE, supra note 73, at 1.

80. Business AND HIV/AIDS, supra note 47 , at III.

81. Id. ("[C]ustomers-both consumers and particularly small and medium enterprises—often remain at risk.").

82. HIV/AIDS AND WoRK, supra note 45 , at 18.

83. Id. at 11 . 
bers to provide care and support to the sick and to provide proper funerals and burials intensify already fragile familial and communal structures. ${ }^{84}$ The death of a family's wage earner often leads young people to enter the workforce prematurely in order to support their remaining family. ${ }^{85}$ Especially negative longterm effects ensue when the death of a family's provider forces a child to leave school and begin to work. ${ }^{86}$

The AIDS crisis continues to aggravate the macroeconomic consequences in many of the poverty-stricken regions in which MNCs operate, ${ }^{87}$ where the epidemic is linked to reduced gross domestic product (GDP). ${ }^{88}$ The GDP in subSaharan Africa is believed to have already decreased by 2 to 4 percent as a result of both the direct and indirect costs of AIDS. ${ }^{89}$ Additionally, there may be decreased interest in financial investment throughout the country or region as investors remain cautious in light of economic and health instability.

No MNC is immune from the effects of the AIDS epidemic. ${ }^{90}$ Even taking account of the many variables that may shape the severity with which the AIDS epidemic affects the profits, costs, and productivity of any given business, "[i]t is inevitable that a firm doing business in the developing world will pay for AIDS. It is just a question of when and how much." "I In addition to increased awareness of the economic impact of the AIDS epidemic on the global workforce and the business operations of MNCs, good business sense dictates that prevention and

84. Id.

85. Id.

86. Id. at $11,31-32$.

87. 2004 REPORT, supra note 53, at 8-9.

88. HIV/AIDS AND Work, supra note 45, at 5, 12-15. While the economic consequences in countries with a high occurrence rate of infection can be astronomical, it is difficult to measure the economic impact of AIDS in countries that are heavily populated but whose infection rate is low relative to the population. This difficulty applies to countries including India, China, Brazil, and the United States, even though each of these countries has more than a million HIV-infected citizens. Id. at 5 .

89. Action Against AidS: The Africa Region, supra note 65.

90. But see HIV/AIDS AND WORK, supra note 45, at 12 (suggesting that the size of the business as well as the level of expertise and skill required of the business' employees are factors that may exacerbate the felt effects).

91. HIV/AIDS in the Work Place, supra note 73, at 1 (quoting Lee Smith, Former President, Levi Strauss International). 
treatment plans be considered without delay before AIDS takes a further toll on the workforces of MNCs. ${ }^{92}$

\section{Intervention Is Cost-Effective}

The global AIDS epidemic is a business issue deserving the attention of MNCs; studies suggest that intervention outweighs cost. The Center for International Health at Boston University, for example, focused on southern Africa's formal business sector and developed a "costing model that estimates the present value of new HIV infections. ${ }^{\text {"93 }}$ The research indicates that:

new infections can cost between 3.4 percent and 10.7 percent of annual salaries depending on skill level, associated benefits, and prevalence in the area. While treatment costs will vary considerably among companies depending on what segment of the workforce is targeted and the type of care offered ... even for low-cost companies, the benefits associated with interventions appeared to outweigh the costs. ${ }^{94}$

Other studies suggest similar conclusions. Findings have shown that turnover rates, as well as labor costs, are reduced through corporate efforts aimed both at prevention and provision of medical care for opportunistic and sexually transmitted infections. ${ }^{95}$ A survey conducted in Kenya exemplifies the economic reality of the issue. While costs relating to HIV/AIDS may reach as much as an average of U.S. $\$ 56$ annually per employee by 2005 if the infection rate continues to expand at its current pace, for as little as U.S. $\$ 15$ per employee for the first year of implementation, an inclusive prevention plan can be provided. ${ }^{96} \mathrm{Re}$ -

92. A former taskforce co-chair for the Corporate Council of Africa, Joe Sills, suggests that:

[a] corporation is going to come out far better by dealing initially with AIDS in its work force and trying to provide information to its families, than simply saying, "This is going to cost a lot of money up front." In training middle management, if these people drop like flies from AIDS, it will cost them a fortune.

Donnelly, supra note 35.

93. HIV/AIDS in the WORK PLACE, supra note 73, at 2.

94. Id. (emphasis added).

95. Action Against AIDS, supra note 48.

96. Id. 
search drawn from specific regions indicates a cost-benefit analysis favoring early intervention. It is much harder to draw general conclusions concerning cost-effectiveness, given the great range of variables:

For example, a business operating in an existing high prevalence region or locality where the epidemic is well-advanced may have a very different cost-benefit scenario than a business located in an area where HIV incidence is relatively low but increasing. The former may see care and treatment programs for its workforce as a priority whereas, for the latter, an education and prevention campaign would bring cost-effective benefits. Other variables affecting cost may include: size of company, setting, industry sector, cost margin, ratio of skilled to unskilled workers, risk factors, HIV prevalence in the workforce, availability of government or NGO supported programs and facilities, etc. ${ }^{97}$

The importance of assessing the impact of AIDS on the business operations of MNCs cannot be overemphasized. Because of the great number of variables involved, successful policy and program implementation depends on first recognizing and understanding the current impact of the epidemic on a specific workplace. A business may evaluate its individual situation by using tools such as the AIDS Impact Model for Business (AIM-B) designed by The Futures Group. ${ }^{98}$ The instrument, which assists in evaluating the situation based on the cost and effects of AIDS, was commissioned by the Global Business Council on AIDS and is available for use at no initial cost. ${ }^{99}$ Following assessment, MNCs will have a clearer picture of how operations are directly and indirectly affected by the epidemic and can target policies and programs to meet the AIDS-related needs of both the business as well as the employees.

97. HIV/AIDS IN THE WORKPLACE, supra note 73, at 2. But see id. at 4 (suggesting that "the approximate rate of infection of the workforce ... in most cases, can be assumed to be similar to the rate for the local population.").

98. Futures Group, AIDS Model Developed to Assist Businesses, at http://www.futuresgroup.com/ Media.cfm? page $=$ News\&ID $=2($ Jan. 15, 2002).

99. Id. 


\section{Prevention}

The critical fact at this time is that a majority of the global workforce is HIV-negative. ${ }^{100}$ If MNCs act now, the growing global workforce crisis may be restrained. Corporations are naturally well suited to aid in prevention efforts, as they often have methods of delivery already in place and can provide information regarding the virus and effective methods of protection and prevention. ${ }^{101}$ Coca-Cola, for example, has utilized its product delivery system to provide educational and prevention materials to various regions in Africa. ${ }^{102}$ Shell Thailand participated in the program "Peer Education at the Pump," utilizing its service stations as information hubs. ${ }^{103}$ Prevention offers widespread benefits as a result of increased interconnectedness, both regionally and globally. ${ }^{104}$ Research shows, however, that while prevention is a necessary and effective method of curbing the AIDS crisis, fewer than one in five persons globally currently has access to "HIV prevention services." 105

In addition to providing preventative information and materials, MNCs may further reduce the rate of HIV/AIDS infection by addressing risky behaviors perpetuated by workplace conditions. For example, MNCs employing mobile and migratory workforces have acknowledged and begun to rectify the living situa-

100. HIV/AIDS AND WORK, supra note 45, at 34 ("Such [prevention] programmes are largely lacking in most areas of the public and private sectors, even though everywhere the majority of national human resources are HIV-negative and thus need to, and can benefit from prevention programmes.").

101. See Donnelly, supra note 35.

102. See e.g., id. But see Baker, supra note 18 (discussing condemnation of Coca-Cola "for failing to fulfill its promises to use [its] highly touted distribution and marketing capacity to distribute condoms and AIDS prevention literature throughout the countryside, given that it accesses over 750,000 retail 'partners' in every African country except Libya and Sudan.").

103. HIV/AIDS in the Work PLace, supra note 73, at 18; Business for Social Responsibility, HIV/ AIDS in the Workplace (2003), at http://bsr.org/CSRResources/IssueBriefDetail.cfm? DocumentID= 49032 [hereinafter HIV/AIDS in the Workplace].

104. Gostin, supra note 11, at 295.

Prevention of HIV/AIDS would benefit all regions and countries, irrespective of the prevalence or incidence of HIV/AIDS in the population. All countries should be concerned about the pandemic, as all social and economic life in the early twentyfirst century is interconnected. HIV/AIDS in one part of the world is bound to affect the health, economy, and security of countries everywhere.

Id.

105. 2004 RePORT, supra note 53, at 11 (suggesting that "[c]omprehensive prevention could avert 29 million of the 45 million new infections projected to occur this decade"). 
tions contributing to extremely high rates of infection among mining and other industry workers. ${ }^{106}$ Prevention programs that take into account regional and workplace conditions, as well as cultural specificities, are best suited to reduce HIV/AIDS infection and transmission rates. ${ }^{107}$

\section{Treatment}

While prevention programs are a crucial step toward slowing and reversing the global workforce crisis, such programs fail to speak to workers already infected and the resulting decrease in productivity. Although a host of variables must again be considered in determining the true cost-effectiveness of treatment programs, reports have found that "many firms have concluded that the direct and indirect costs of inaction are far greater than the costs of treatment[,]"108 and that "treatment programmes in the workplace... are increasingly seen by a range of enterprises as the least costly option to maintain profitability and ensure growth." 109 Presently, no known cure for HIV/AIDS exists, but antiretroviral drug treatment may substantially slow the physical devastation caused by the virus and even reverse the effects in advanced cases. ${ }^{110}$

Treatment is a complicated proposition. It holds great promise, but concerns have been raised regarding severe side-effects. ${ }^{111}$ A second fear is the danger of creating resistant strands of the virus if the necessary infrastructure needed to monitor effective use is not available or if patients do not fully adhere to treatment plans. ${ }^{12}$ Beyond the difficulty of administration, the cost of treatment

106. See, e.g., UNAIDS \& U.N. Department of Public Information, HIV/AIDS: Ir's Your Business at 19, U.N. Doc. UNAIDS/03.41E (2003) (praising Gold Fields Ltd. and Lomin Platinum for "replacing all-male hostels with accommodation for families in a bid to prevent HIV transmission and foster a more stable workforce") [hereinafter HIV/AIDS: It's Your Business]; HIV/AIDS in the WoRk PLACE, supra note 73, at 13.

107. Code of Practice, supra note 32, at 4.

108. HIV/AIDS AND WoRK, supra note 45 , at XI.

109. Id. at XII.

110. Robert Baker, Prevention, Not Cheap Drugs, Can Eradicate AIDS in Africa, in AIDS: OpposING Viewpoints, supra note 44, at 48, 49 ("With these drugs you can prevent HIV from developing into full-blown AIDS and even bring the desperately ill back from the brink.").

111. See, e.g., Celia Farber, AIDS Drugs Are Deadly, in AIDS: Opposing VIEwpoints, supra note 44 , at $184,185-89$.

112. See Baker, supra note 110, at 49-51; José M. Zuniga, Africa Needs Better Infrastructure, Not Drugs, to Fight AIDS, in AIDS: Opposing Viewpoints, supra note 44, at 58, 59-61; Catherine Campeell, 'Letting Them Die': Why Hiv/aids Prevention Programmes Fail 6 (2003). 
often stands as an obstacle to access. ${ }^{113}$ Estimates provided by the World Health Organization suggest that only one out of ten individuals requiring antiretroviral treatment is actually receiving such treatment. ${ }^{114}$

In spite of the intrinsic difficulties, several MNCs have implemented treatment programs. In 1996, Volkswagen of Brazil created a care program for its employees, which included access to drug treatment. ${ }^{115}$ Three years later, the corporation found "a 90 [percent] reduction in hospital admissions; a 40 [percent] reduction in the costs of treatment and care ... and [a reduction in] the heavy costs experienced through absenteeism and death of skilled employees." 116 In addition to its already existing prevention programs, the global mining conglomerate Anglo American plc more recently instituted a treatment program aimed at workers not already covered by health-care benefits. ${ }^{117}$ The company estimates that nearly 25 percent of its South African workforce is HIV-positive. ${ }^{118}$ In 2003, costs related to treatment and monitoring approximated U.S.\$1,150 per employee per year. ${ }^{119}$ The cost-effectiveness of treatment is extremely evident: in the first year alone, mortality rates dropped from 30 percent to 3.4 percent. ${ }^{120}$ AIDSrelated medical costs and absenteeism have also declined. ${ }^{121}$ Other MNCs involved in the automotive industry, such as Ford Motor Company South Africa and DaimlerChrysler South Africa, have also led the field in creating and implementing comprehensive work place programs. ${ }^{122}$

113. Cohen, supra note 44, at 55 ("At today's market prices, treating AIDS patients with antiretroviral medicines would cost more than the health care budgets of many developing countries. For some, including Uganda and Zimbabwe, the cost would dwarf the size of their national economies."). But see infra notes 139-141 and accompanying text (arguing that MNCs can use their collective influence to lobby for lower drug prices and other treatment options).

114. See 2004 Report, supra note 53, at 13 (forecasting that within the next 2 years, roughly 5 to 6 million individuals living in developing countries will die if they continue without treatment).

115. ILO, Examples of Workplace Action: Volkswagen do Brazil, at http://www.ilo.org/publid english/protection/trav/aids/examples/brazil.htm (last modified Jan. 19, 2005).

116. Id.

117. HIV/AIDS AND WoRK, supra note 45 , at 48.

118. Id.

119. Id. The company, however, expects the expense to decline over time as a result of economies of scale as well as drug price reduction. Id. at $48-49$.

120. Id. at 49.

121. Id.

122. See, e.g., Sarah Meyers, South Africa: The Destructive Impact of HIV/AIDS on the Automotive Sector (2001), at http://www.worldmarketsanalysis.com/InFocus2002/articles/africa_HIV_ safrica.htm (last visited Apr. 6, 2005). 
Treatment programs properly implemented can have a positive impact on the global work force crisis:

[m] any people once relegated to the economic sidelines because of disease are now able to work, earn a living, and acquire the necessities of life that permit an ever-improving standard of living. ... This increase in productivity raises the level of economic activity, enabling more and more businesses to invest in their employees' health.

Healthy workers are a key part of the cycle that increases productivity and leads to greater investment that results in medical innovations and improved human health. ${ }^{123}$

Clearly, a delicate and careful combination of prevention and treatment is necessary to permanently curb the impact of AIDS on the global workforce. ${ }^{124}$ Framing AIDS as a global work force crisis illustrates how cost-effective intervention can be.

123. William C. Steere, Jr., The Role of Business, in Critical Issues in Global Health 399, 400 (C. Everett Koop et al. eds., 2001) (emphasis added).

124. 2004 REPORT, supra note 53, at 11 ("Although antiretroviral treatment is bringing hope to millions, without sharply reducing the number of new HIV infections, expanded access to treatment becomes unsustainable. Providers of antiretroviral treatment will be swamped by demand."); see also Business and HIV/AIDS, supra note 47, at II (Peter Piot, Executive Director of UNAIDS, advises that the HIV-infection rate of the countries in which a company does business should help to guide decisions regarding whether to focus predominantly on workplace policies and prevention or treatment alongside of prevention programs.). Although work place prevention and treatment programs combine to curb the direct negative impact of the AIDS epidemic with regard to increased costs as well as reduced productivity and profits, some corporations choose to side-step the issue completely by indirect, and ultimately ineffective, means. The ILO notes that "[s]ome companies have outsourced production activities, shifted from labour-intensive to capitalintensive technologies, or attempted to avoid hiring new employees who may be HIV-positive (or who belong to seemingly high-risk groups)." HIV/AIDS AND WORK, supra note 45, at 19. Furthermore, "anecdotal evidence from diverse sources [suggests] that pre-employment testing is taking place in high-prevalence countries, even where this is against the law or national policy." Id. These actions, however, do not provide a sustainable solution and, therefore, should not be viewed as legitimate responses. 


\section{Limitations and Criticisms Under a Corporate Responsibility Framework Dispelled Under the Global Workforce Crisis Framework}

This Part concludes with the suggestion that the proposed framework of AIDS as a global workforce crisis may dispel limitations and criticisms inherent under the current framework of corporate social responsibility - the voluntary nature and lack of enforcement, the "bottom line" as the only concern of MNCs, and the insufficiency and nonsustainability of the current response.

\section{Lack of Enforcement and Voluntary Nature}

While the proposed framework does not alter the underlying voluntary nature of action, it does reinforce existing, and provide additional, internal motivation for MNCs to act. As MNCs take ownership of the crisis and realize that responsiveness also serves their "self-interest, to protect [their] investment," 125 the incredible need for methods of enforcement dissipates. Enforcement mechanisms, in fact, are only necessary in circumstances where internal motivations do not suffice as a driving force for action.

Enforcement between MNCs will also develop to prevent the possibility of regional "free-riders." Corporations concerned with curbing the threat to the global workforce will force fellow corporations to internalize AIDS-related costs, for "[w]here a company is making efforts to reduce the rate of infection within its own workforce, it is in that company's best interests that its neighbors-even its competitors-do likewise." 126 The resulting regional and global business coalitions serve as tools of accountability. ${ }^{127}$ Individual nations have also established business coalitions against AIDS. ${ }^{128}$

125. Son, supra note 5 (quoting AKM Shamsuddin, president of the Foreign Investors Chamber of Commerce).

126. HIV/AIDS in the WORKPLACE, supra note 73, at 19.

127. See, e.g., Global Business Coalition on AIDS, at http:/www.businessfightsaids.org/site/ pp.asp? $\mathrm{c}=\mathrm{nmK}$ 0LaP6E\&b=89994 (last visited Apr. 6, 2005); World Health Organization, Interna tional HIV Treatment Access Coalition, at http://www.who.int/hiv/itac/en/ (last visited Apr. 6, 2005); World Economic Forum, Global Health Initiative, at http:/www.weforum.org/site/homepublic. nsf/ Content/Global + Health + Initiative (last visited Apr. 6, 2005); Asian Business Coalition on AIDS, at http://www.abconaids.org/ABC/asp/view.asp? PageID $=1 \&$ SiteID $=0 \& L$ angID $=0 \&$ MenuID = $0 \&$ SponsorID $=50$ (last visited Apr. 6, 2005); and Centers for Disease Control and Prevention, Business Responds to AIDS and Labor Responds to AIDS, at http://www.brta-Irta.org/ (last visited Apr. 6, 2005).

128. Action Against AIDS: The Africa Region, supra note 65 ("Some countries have also set up specific business coalitions against AIDS, including Botswana, Cameroon, Ethiopia, Kenya, Namibia, Nigeria, South Africa, Swaziland, Uganda and Zambia."). 
MNCs will also answer to partnerships with NGOs and other non-MNC entities such as the joint ventures between DaimlerChrysler South Africa and the German Technical Cooperation Agency; ${ }^{129}$ Unilever and the Ghana Social Marketing Foundation; ${ }^{130}$ and Heineken with PharmAccess International and the German Development Co-operation. ${ }^{131}$ Another example of a unique partnership forged as a result of the emerging AIDS epidemic is between the insurance firm American International Assurance Thailand and businesses operating in Thailand. As an incentive to promote HIV/AIDS action on the part of employers, the insurance company offers group life insurance premium discounts of 5 to 10 percent to companies engaged in effective nondiscriminatory and preventative HIV/ AIDS practices in the workplace. ${ }^{132}$

Finally, the concern that MNCs will "fold up" business and move elsewhere in the face of too much external pressure cannot hold true. Not only are there vast expenses in reestablishing operations and bringing a new workforce up to speed, but statistics substantiate the reality that MNCs will face the global AIDS crisis wherever they operate. ${ }^{133}$

\section{The "Bottom Line" As Multinational Corporations' Only Concern}

Is viewing the AIDS crisis in terms of economic implications truly as harmful as some critics believe? ${ }^{134}$ If, "[a]t the micro level, businesses will feel the impact of HIV/ AIDS most clearly through their workforce, with direct consequences for a company's bottom line,"135 then this recognition will encourage, rather than discourage, MNCs to act. Even Kofi Annan, United Nations Secretary-General, recognized the importance of using the language of corporate costs and profits to induce action:

It is high time we tapped the strengths of the business sector to the full. AIDS affects business. The spread of the pandemic has

129. HIV/AIDS: IT's Your BusINess, supra note 106, at 21.

130. HIV/AIDS IN THE WoRK PLACE, supra note 73, at 7.

131. Id. at 17.

132. Son, supra note 5; HIV/AIDS IN THE WORKPLACE, supra note 73, at 18; HIV/AIDS in the Workplace, supra note 103.

133. Julia Hanna, How Corporate Responsibility is Changing in Asia (Feb. 23, 2004), at http:// hbswk.hbs.edu/pubitem.jhtml?id=3932\&t=special_reports_asia2004 (Nike serves as an example of a corporation realizing that even if it was required to spend more money [here, on wages], it still had "a pretty good deal.").

134. See, e.g., Hunter, supra note 68 , at 209-10.

135. HIV/AIDS IN THE WORKPLACE, supra note 73, at 1 (emphasis added). 
caused business costs to expand, and markets to shrink. As both the current balance sheet and future indicators show, the business community needs to get involved to protect its bottom line. ... There are already several examples that prove the unparalleled positive impact that corporate action can have in the fight against HIV/AIDS. It is time to turn those examples into concerted and strategic action in the workplace, in advocacy and in building on ... corporate strengths. ${ }^{136}$

If the criticism that MNCs possess too much power and influence globally is indeed true, then corporations can use it to push for further reductions in antiretroviral drug prices. Although prices of antiretroviral drugs appear to be dropping due to current pressure on the pharmaceutical industry, ${ }^{137}$ the price remains extremely high in some regions. ${ }^{138}$ MNCs can join forces and negotiate with drug companies to reduce rates for bulk purchases. ${ }^{139}$ They can also use their enormous lobbying power for research and development of other, easier to administer, treatment options such as an AIDS vaccination ${ }^{140}$ and microbicides. ${ }^{141}$

136. HIV/AIDS: It's Your Business, supra note 106, at 3 (quoting Kofi Annan, United Nations Secretary-General, in a speech given to the U.S. Chamber of Commerce, Washington, DC, in June 2001). 137. 2004 REPORT, supra note 53, at 14 (stating that in 2000, the price for a World Health Organizationsuggested treatment regimen ranged from $\$ 10,000$ to $\$ 12,000$ per patient per year, but now some generic versions are available for $\$ 300$ per person per year).

138. Id. (listing Russia and Serbia as 2 countries in which antiretroviral medicines remain prohibitively expensive).

139. HIV/AIDS: It's Your Business, supra note 106, at 20.

140. Baker, supra note 110 , at 51 .

[W] hat the banners of protestors outside the drug companies ought to be saying is not "Free Drugs" but "Where Are Your Vaccines?". Most vaccines require one or two injections, in contrast to a lifetime's dependence on drugs that are proving highly lucrative, for the pharmaceutical industry. The number of scientists working on HIV vaccines throughout the world is about 100 . Almost none of them work for commercial drug companies.

Id. See also Bill Snow, An AIDS Vaccine Is Needed to End the Epidemic, in AIDS: Opposing VIEwPOINTs, supra note 44, at 137, 138-141. Snow suggests that "[v]accines are the most cost-effective medical intervention of all time, the only way any disease has ever been eradicated." Id. at 139. Not all critics, however, agree on the necessity or importance of developing an HIV vaccination. For instance, Charles Krauthammer asks, "Why embark on a huge national venture to create a vaccine for a disease that is already extraordinarily preventable?" An AIDS Vaccine Is Not Needed to End the Epidemic, in AIDS: Opposing Viewpoints, supra note 44, at 142-43. He suggests instead that traditional methods of stopping the spread of infectious disease be employed, including "identifying carriers and warning their contacts." Id. at 144.

141. See 2004 Report, supra note 53, at 15. 


\section{Insufficiency/Nonsustainability of the Current Response of MNCs}

The final criticism under the framework of corporate social responsibility will be dispelled as prevention and treatment prove cost-effective to MNCs. Short-term and inconsistent action does not equate with cost-effectiveness, and, therefore, the economic reality of the situation will require MNCs to commit enough time and resources to provide responses that are significant, lasting, and effective against the global workforce crisis.

\section{Conclusion}

As "no single approach to resource mobilization is likely to overcome HIV/ AIDS," 142 this Note develops an additional language by which both MNCs and their critics may engage in meaningful and persuasive dialogue regarding the appropriate and necessary responses to the global AIDS crisis. The impact of the AIDS epidemic on the global workforce as well as on the costs, productivity, and profits of MNCs provides renewed internal motivation not present under the corporate social responsibility framework. Critics who present strong evidence of the impact of the AIDS epidemic on the global workforce and the cost-effectiveness of intervention provide an internal, economically-focused motivation to act. Focusing on the workforce crisis model to the exclusion of human rights and corporate responsibility may, however, be a risky proposition. Cost-effectiveness arguments will not necessarily carry the same weight in every situation. On these occasions, action must still be urged on the basis of corporate social responsibility.

MNCs hold a unique position of effectiveness against this global devastation. ${ }^{143}$ Greater incentive, creativity, action, and commitment on the part of MNCs transpire when critics frame the issue in terms that make good business and economic sense. Perhaps the talk will no longer end in the newspaper, ${ }^{144}$ the law journal article, or the corporate code of conduct. Through meaningful and persuasive dialogue, "the talk" will end in deliberate, decisive, and significant action by MNCs.

142. Currie, supra note 64 , at 128.

143. Schwab, supra note 47, at I. ("[T]he role of business will continue to evolve as businesses explore how to best contribute their strengths and capabilities to address areas of greatest need.").

144. Fugard et al., supra note 1 , at 4. 


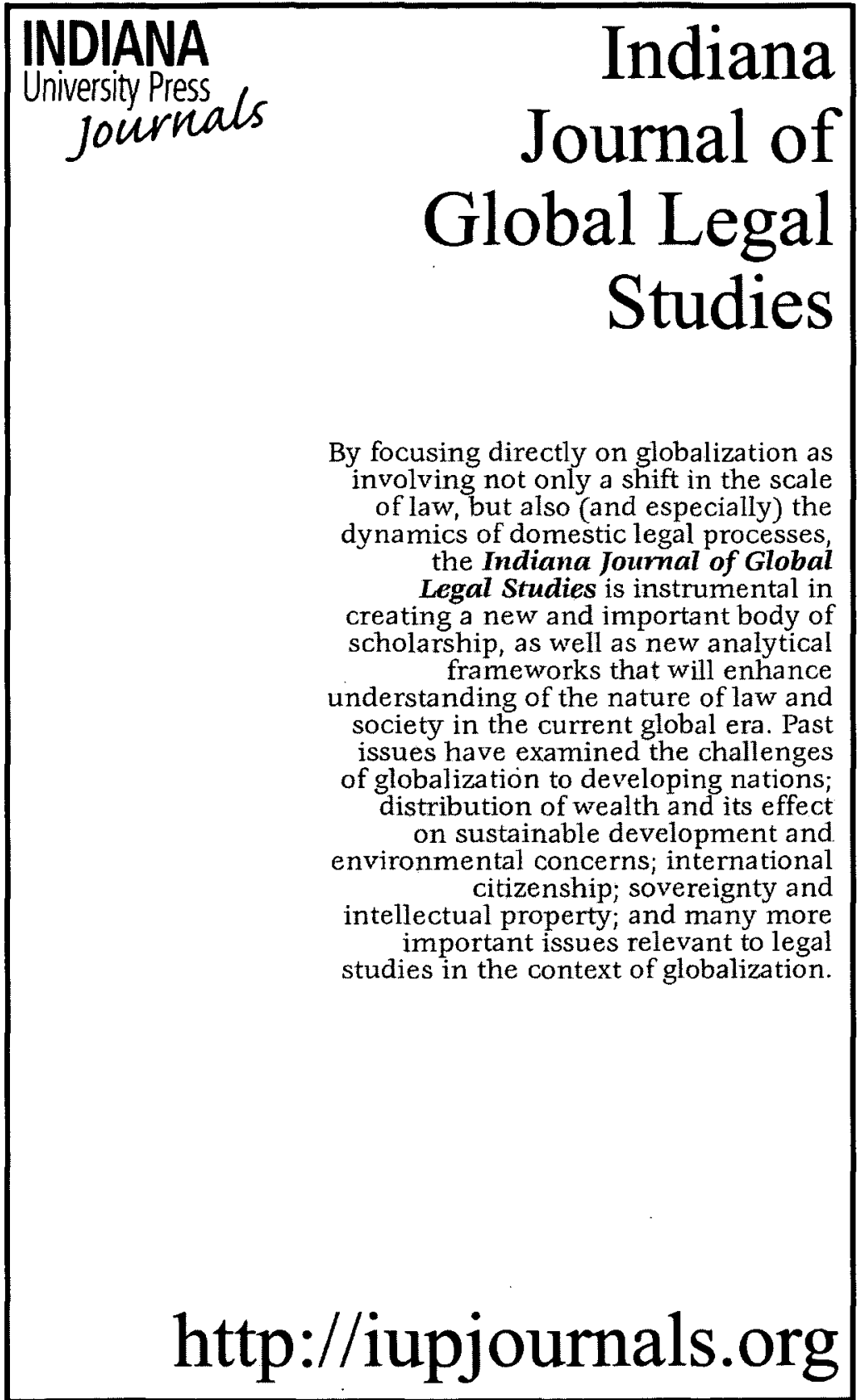

